\title{
Bitter Melon (Momordica charantia L.) Fruit Bioactives Charantin and Vicine Potential for Diabetes Prophylaxis and Treatment
}

\author{
Mahwish ${ }^{1}$, Farhan Saeed ${ }^{1}$, M. Tauseef Sultan ${ }^{2}$, Ayesha Riaz ${ }^{3}$, Sagheer Ahmed ${ }^{4} \mathbb{D}^{\text {, Nicusor Bigiu }}{ }^{5}$, \\ Ryszard Amarowicz ${ }^{6, *(D)}$ and Rosana Manea ${ }^{5}$ (D)
}

check for

updates

Citation: Mahwish; Saeed, F.; Sultan, M.T.; Riaz, A.; Ahmed, S.; Bigiu, N.; Amarowicz, R.; Manea, R. Bitter Melon (Momordica charantia L.) Fruit Bioactives Charantin and Vicine Potential for Diabetes Prophylaxis and Treatment. Plants 2021, 10, 730. https://doi.org/10.3390/

plants10040730

Academic Editor: Corina Danciu

Received: 17 March 2021

Accepted: 5 April 2021

Published: 8 April 2021

Publisher's Note: MDPI stays neutral with regard to jurisdictional claims in published maps and institutional affiliations.

Copyright: (c) 2021 by the authors. Licensee MDPI, Basel, Switzerland. This article is an open access article distributed under the terms and conditions of the Creative Commons Attribution (CC BY) license (https:// creativecommons.org/licenses/by/ $4.0 /)$.
1 Institute of Home \& Food Sciences, Government College University, Faisalabad 38000, Pakistan; mahwishyounas@yahoo.com (M.); f.saeed@gcuf.edu.pk (F.S.)

2 Institute of Food Science and Nutrition, BZU, Multan 60800, Pakistan; tauseefsultan@bzu.edu.pk

3 Institute of Home Sciences, University of Agriculture, Faisalabad 38000, Pakistan; i_sha_r@yahoo.com

4 Shifa College of Pharmaceutical Sciences, Shifa Tameer-e-Millat University, Islamabad 44000, Pakistan; sagheer.scps@stmu.edu.pk

5 Faculty of Medicine, Transilvania University of Brasov, 500019 Brasov, Romania; nicusorbigiu@yahoo.com (N.B.); rosanamanea@gmail.com (R.M.)

6 Institute of Animal Reproduction and Food Research, Polish Academy of Sciences, 10-748 Olsztyn, Poland

* Correspondence: r.amarowicz@pan.olsztyn.pl

\begin{abstract}
Natural products are gaining clinical significance in modern day health care systems to prevent diseases. Bitter melon, a health promoting vegetable, is traditionally used for medical nutrition therapy to cure diabetes but to reap maximum health claims, vigilant control of its substances in diet is crucial as part of curative action for effective diabetes management. In the present research, first phase focused on detection of key bioactive components, i.e., charantin and vicine in different parts of its fruit. In the second phase, normal and hyperglycemic Sprague Dawley rats were fed on skin, flesh and whole fruit of bitter melon at 150 and $300 \mathrm{mg} / \mathrm{kg}$ body weight and assessed for diabetes prophylaxis and treatment. The highest amount of charantin $(0.16 \pm 0.02 \mathrm{mg} / \mathrm{g})$ was recorded in flesh while vicine was present in abundance in whole fruit $(0.21 \pm 0.01 \mu \mathrm{g} / 100 \mathrm{~g})$. In normal rats, bitter melon supplementation was helpful in managing the onset of diabetes. Hyperglycemic rats showed diabetic complications including polydipsia, polyuria, glycosuria, renal hypertrophy and increased glomerular filtration rate. However, bitter melon consumption showed significant improvements in these parameters. The most potent dose was $300 \mathrm{mg} / \mathrm{kg}$ whole fruit that resulted in $31.64 \%$ lowering of blood glucose level and $27.35 \%$ increase in insulin level in hyperglycemic rats.
\end{abstract}

Keywords: bitter melon; Momordica charantia; diabetes; charantin; vicine; glycemic control; hypoglycemia

\section{Introduction}

Sedentary lifestyle and poor dietary habits lead towards occurrence of various disorders such as diabetes, cardiovascular diseases, hypertension, etc. Plants and their products have tendency to ameliorate such disorders and can play a helpful role in preventing diseases. The dietary components play an integral part in promoting the health due to presence of phytochemicals and phytonutrients. They are helpful in mitigating serious disorders such as diabetes, hypercholesterolemia, hyperlipidemia, inflammation, etc.

Bitter melon (Momordica charantia L.) is considered due to its chemical moieties [1]. The bitter melon is a member of family Cucurbitaceae and is also known as balsam pear, bitter gourd and karela in different regional languages. It is consumed as a vegetable in different tropical and subtropical regions of world, owing to its distinctive taste and nutritional profile. Green fruits of bitter melon contain vitamin A, C, thiamine, niacin, riboflavin and minerals [2]. It naturally possesses high phenolic content, i.e., gallic acid, alkaloids, saponins, flavonoids, etc. Due to this rich phytochemistry, bitter melon exhibits 
highest antioxidant activity among its family. Owing to the presence of various bioactive components, bitter melon holds some pharmacological properties and exerts various health enhancing properties such as scavenging of free radicals, hypoglycemic and hypolipidemic activities [3]. Diabetes mellitus is a growing threat to human health that affects millions of peoples each year. The dietary patterns significantly influence the pathogenesis of diabetes mellitus by incorporating healthy foods in normal diets along with physical activity is an effective strategy. Many studies suggest the effectiveness of bitter melon against diabetes prophylaxis [4-9]. Many in vivo studies confirmed the hypoglycemic potential of bitter melon and treatment due to the presence of numerous hypoglycemic agents such as alkaloids, flavonoids, saponin, catechins, charantin, vicine, and polypeptide$p$ fractions [10]. Many experiments supported that bitter gourd proved to be effective in insulin production and can be hepato-renal protective. However, inadequacies were present in most of the studies due to poor study design [11]. Furthermore, some hypoglycemic studies reported contradictory results with negligible positive effects of bitter melon intake during diabetes $[12,13]$. In many studies, the data were insufficient and indecisive to advocate its use in diabetes management $[11,14]$. Some studies evaluated effectiveness of only specific part of bitter melon with single dosage for limited time period [12]. In these studies, no information was provided in relation to role of bioactive molecules in diabetes management. It was, therefore, important to conduct a more conclusive and systematic study. Hence, present study was designed to compare different parts of bitter melon fruit for charantin and vicine contents and subsequent feeding trial to assess individual or combined role of these natural products in improving diabetes and associated complications.

\section{Materials and Methods}

\subsection{Procurement and Handling of Raw Material}

Bitter melon fruits were procured from Vegetable Research Section, Ayub Agriculture Research Institute, Faisalabad, Pakistan. These fruits were washed carefully to remove adhered unhygienic substances and other contaminants. After washing, the outer warty skin was peeled and collected separately. After peeling, flesh part was obtained by removing seeds. Some fruits were cut into small size as a whole. These isolated fruit portions were kept for few days at room temperature to dry. Fine powder was made of this dried material by using laboratory grinder (Panasonic, Osaka, Japan, Model MJ-W176P) and absolute refined powder was collected by passing through a sieve and finally packed separately in glass bottles for further evaluation.

\subsection{Reagents and Standards}

HPLC grade reagents and standards were purchased from Sigma-Aldrich (Tokyo, Japan) and Merck (Darmstadt, Germany). Diagnostic kits were purchased from Cayman Chemicals (Europe) and Sigma-Aldrich Bioassay (Darmstadt, Germany).

\subsection{Quantification of Charantin}

The estimation of charantin contents in samples were determined by protocol of Pitipanapong et al. [15]. Firstly, $1.0 \mathrm{~g}$ powder of bitter melon samples was taken to extract with ethanol and further extracted in methanol by ultra-sonication. In this way, viscous crude extract of charantin was obtained by filtration of extracts and subsequent evaporation. Before analyzed by HPLC, crude extract was purified. HPLC analysis was performed with C-18 Inertsil ODS-3 column (size of particles $5.0 \mu \mathrm{M}, 4.6 \mathrm{~mm} \times 250 \mathrm{~mm}$ ID). Methanolwater $(100: 2 \mathrm{v} / \mathrm{v})$ was used as mobile phase with $1 \mathrm{~mL} / \mathrm{min}$ flow rate. The wavelength for UV detection was $204 \mathrm{~nm}$ and volume for sample injection was $200 \mu \mathrm{L}$.

\subsection{Quantification of Vicine}

The extraction of bitter melon powder samples was done with water (10-25 mL) for ten min by ultra-sonication. The mixture was centrifuged and supernatant was collected separately in volumetric flask. All the samples were filtered before analysis through HPLC. 
HPLC analysis was performed with C-18 reversed phase column $250 \mathrm{~mm} \times 4.6 \mathrm{~mm}, 5 \mu \mathrm{M}$ ). Methanol-phosphate buffer with pH $3.0(10: 90, v / v)$ was used as mobile phase. Detector was set at $280 \mathrm{~nm}$ [16].

\subsection{Efficacy Study}

To probe anti-diabetic effect of bitter melon, Sprague Dawley rats were kept in Animal Room, College of Pharmacy, Government College University, Faisalabad. Prior to feeding trial, rats were acclimatized by giving basal diet for few days. During eight week feeding trial, temperature and relative humidity was maintained to $25 \pm 2{ }^{\circ} \mathrm{C}$ and $55 \pm 5 \%$, respectively, with regular alteration in light/dark period consisting of $12 \mathrm{~h}$. Central Government Ethical Committee Guidelines were strictly followed during the course of study (Approval no. FSD-16/M-234).

\subsection{Diet and Dosage}

For control group, the diet is composed of $66 \%$ corn starch, $10 \%$ corn oil, $10 \%$ cellulose, $10 \%$ protein contents, $3 \%$ minerals and $1 \%$ vitamin mixture. For experimental groups, skin, flesh, whole fruit powder of bitter melon in doses of $150 \mathrm{mg} / \mathrm{kg}$ and $300 \mathrm{mg} / \mathrm{kg}$ body weight was added. In this way, seven groups of rats were made consisting of twenty rats in each group. Each group is further split into normal rats and hyperglycemic rats. The normal rats were given diet without excessive sucrose while hyperglycemic rats were given $40 \%$ sucrose in diet to induce hyperglycemia and diabetes. The rats were given access to water and feed on ad libitum basis.

\subsection{Testing}

Each group was observed for water intake, feed intake and weight gain in $24 \mathrm{~h}$ period during the course of the study. The volume of urine was also noted by using metabolic cages in which rats were placed for $24 \mathrm{~h}$ and collected urine under a layer of toluene. The amount of reducing sugar in urine of rats was determined by 3,5-dintro salicylic acid method [17]. Creatinine was measured in blood and urine by Owen's method [18]. Glomerular filtration rate (GFR) was assessed by following formula [19]:

$$
=\frac{\operatorname{GFR}(\mathrm{ml} / \mathrm{min})}{\text { Urine volume }(\mathrm{ml}) \times \text { Urinary Creatinine }(\mathrm{mg} / \mathrm{dl}) \times 1000(\mathrm{~g})}
$$

Blood samples were collected in EDTA coated tubes at 28 and 56 day of trial. Isolation of serum was done by centrifugation @ 4000 rpm for 6 min in centrifuge machine (Rotrofix 32-A Heltich, Westphalia, Germany). For biochemical evaluation, these samples of sera were kept through Microlab (Rendox Toerauta RX-Monza, County Monaghan, Republic of Ireland). The glucose and insulin level was calculated by procedure of Katz et al. [20] and Ahn et al. [21], respectively. The percent increase or decrease in biochemical traits of experimental groups was calculated in comparison to control groups. At the end of trial, the weight of the right and left kidneys were determined separately.

\subsection{Statistical Analysis}

The data was statistically analyzed using Statistical Package (Microsoft Excel 2016 and SPSS v20.). Level of significance was determined by ANOVA and LSD for comparison [22].

\section{Results}

\subsection{Quantification of Charantin and Vicine}

The charantin and vicine contents (Figure 1) in different bitter melon fruit parts were determined through HPLC before administration of diet to Sprague Dawley rats. The total amount of charantin was found high in flesh part $(0.16 \pm 0.02 \mathrm{mg} / \mathrm{g})$ than whole fruit $(0.11 \pm 0.02 \mathrm{mg} / \mathrm{g})$ and skin $(0.08 \pm 0.01 \mathrm{mg} / \mathrm{g})$. Meanwhile, whole fruit possessed high 
amount of vicine $(0.210 \pm 0.010 \mu \mathrm{g} / 100 \mu \mathrm{g})$ than flesh $(0.131 \pm 0.005 \mu \mathrm{g} / 100 \mu \mathrm{g})$ and skin $(0.114 \pm 0.006 \mu \mathrm{g} / 100 \mu \mathrm{g})$.

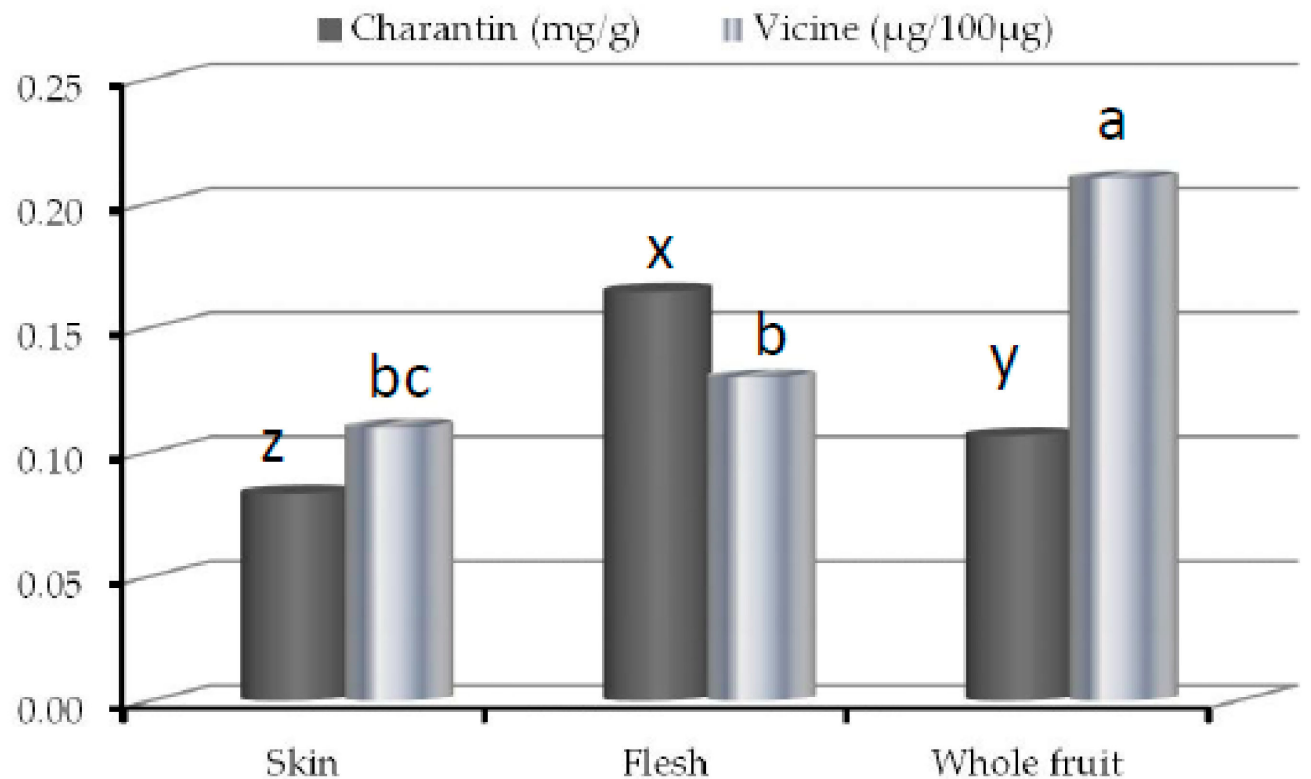

Figure 1. Charantin and vicine contents in skin, flesh and whole fruit of bitter melon. $x, y, z$ indicated significant differences in charantin contents $(p<0.05) ; \mathrm{a}, \mathrm{b}, \mathrm{c}$ indicated significant differences in vicine contents $(p<0.05)$.

\subsection{Feed and Water Intake}

The diet containing bitter melon fruit skin, flesh and whole fruit at the doses of 150 and $300 \mathrm{mg} / \mathrm{kg}$ body weight increases the consumption of water in normal rats with highest increase was observed in rats fed with $300 \mathrm{mg} / \mathrm{kg}$ body weight of whole fruit (Table 1).

Table 1. Impact of bitter melon supplementation on water intake of rats.

\begin{tabular}{ccccc}
\hline & \multicolumn{3}{c}{ Water Intake (mL/24 h) } \\
\cline { 2 - 5 } Groups & \multicolumn{2}{c}{ 28th day } & 56th day \\
\cline { 2 - 5 } & Normal Rats & Hyperglycemic Rats & Normal Rats & Hyperglycemic Rats \\
\cline { 2 - 5 } & $23.7 \pm 1.15^{\mathrm{d}}$ & $29.35 \pm 2.15^{\mathrm{a}}$ & $27.9 \pm 2.12^{\mathrm{d}}$ & $36.65 \pm 2.05^{\mathrm{a}}$ \\
Control & $24.1 \pm 1.34^{\mathrm{c}}$ & $25.94 \pm 1.49^{\mathrm{b}}$ & $28.1 \pm 1.77^{\mathrm{c}, \mathrm{d}}$ & $31.02 \pm 2.34^{\mathrm{b}}$ \\
SF-L & $24.3 \pm 1.40^{\mathrm{c}}$ & $24.85 \pm 1.46^{\mathrm{c}}$ & $28.4 \pm 2.15^{\mathrm{c}}$ & $29.01 \pm 2.17^{\mathrm{d}}$ \\
SF-H & $24.4 \pm 1.88^{\mathrm{b}, \mathrm{c}}$ & $25.03 \pm 2.11^{\mathrm{b}}$ & $28.3 \pm 1.63^{\mathrm{c}}$ & $30.85^{\mathrm{c}} \pm 1.69^{\mathrm{c}}$ \\
FF-L & $24.7 \pm 1.35^{\mathrm{b}}$ & $24.07 \pm 1.75^{\mathrm{d}}$ & $28.6 \pm 2.19^{\mathrm{b}}$ & $28.79 \pm 1.56^{\mathrm{e}}$ \\
FF-H & $24.8 \pm 2.01^{\mathrm{a}, \mathrm{b}}$ & $24.91 \pm 1.68^{\mathrm{b}}$ & $28.7 \pm 2.03^{\mathrm{b}}$ & $30.71 \pm 2.62^{\mathrm{c}}$ \\
WF-L & $25.2 \pm 1.48^{\mathrm{a}}$ & $23.86 \pm 1.33^{\mathrm{d}}$ & $29.00 \pm 1.59^{\mathrm{a}}$ & $28.63 \pm 2.22^{\mathrm{e}}$ \\
WF-H & & &
\end{tabular}

SF-Skin fed rats; FF-Flesh fed rats; WF- Whole fruit fed rats; L-Lower amount of bitter melon in experimental diet (150 mg/kg body weight), H-High amount of bitter melon in experimental diet (300 mg/kg body weight); Values are mean \pm SD of ten rats; Superscript letters within the same column indicate significant $(p<0.05)$ differences.

In hyperglycemic rats, consumption of water increased in control and significant reduction in water intake was observed by incorporation of bitter melon in diet in dose dependent manner. Whole fruit and flesh of bitter melon were found more effective than skin in preventing polydipsia conditions in hyperglycemic rats. In normal rats, supplementation of bitter gourd skin, flesh and whole fruit has resulted in reduction of feed intake compared to control while polyphagia condition was noticed in hyperglycemic control rats as they consumed an excessive quantity of diet compared to rats fed with bitter melon (Table 2). 
Table 2. Impact of bitter melon supplementation on feed intake of rats.

\begin{tabular}{ccccc}
\hline & \multicolumn{3}{c}{ Feed Intake (g) } \\
\cline { 2 - 5 } Groups & \multicolumn{2}{c}{ 28th day $^{2}$} & \multicolumn{2}{c}{ 56th day } \\
\cline { 2 - 5 } & Normal Rats & Hyperglycemic Rats & Normal Rats & Hyperglycemic Rats \\
\cline { 2 - 5 } & $15.1 \pm 1.12^{\mathrm{a}}$ & $17.03 \pm 1.78^{\mathrm{a}}$ & $21.2 \pm 2.49^{\mathrm{a}}$ & $23.22 \pm 1.33^{\mathrm{a}}$ \\
Control & $14.6 \pm 0.76^{\mathrm{b}}$ & $14.96 \pm 1.39^{\mathrm{b}}$ & $20.5 \pm 2.03^{\mathrm{b}}$ & $20.94 \pm 1.11^{\mathrm{b}}$ \\
SF-L & $14.3 \pm 1.38^{\mathrm{b}}$ & $13.80 \pm 1.01^{\mathrm{c}}$ & $20.1 \pm 1.98^{\mathrm{b}}$ & $19.78^{\mathrm{b}} \pm 1.04^{\mathrm{c}}$ \\
SF-H & $14.3 \pm 1.22^{\mathrm{b}}$ & $14.94 \pm 0.78^{\mathrm{b}}$ & $20.4 \pm 1.62^{\mathrm{b}}$ & $20.87 \pm 0.92^{\mathrm{b}}$ \\
FF-L & $14.1 \pm 0.94^{\mathrm{b}, \mathrm{c}}$ & $13.76 \pm 1.39^{\mathrm{c}}$ & $19.8 \pm 0.99^{\mathrm{b}, \mathrm{c}}$ & $19.45 \pm 1.17^{\mathrm{c}}$ \\
FF-H & $13.9 \pm 0.45^{\mathrm{c}}$ & $14.82 \pm 1.54^{\mathrm{b}}$ & $19.9 \pm 1.07^{\mathrm{b}, \mathrm{c}}$ & $20.73 \pm 1.43^{\mathrm{b}}$ \\
WF-L & $13.7 \pm 0.88^{\mathrm{c}}$ & $13.64 \pm 1.44^{\mathrm{c}}$ & $19.6 \pm 0.69^{\mathrm{c}}$ & $19.36 \pm 1.36^{\mathrm{c}}$ \\
WF-H & & & &
\end{tabular}

Abbreviations and description as in Table 1.

\subsection{Body Weight Gain}

Normal control rats gained more weight with the passage of time than bitter melon fed rats (Table 3). In hyperglycemic control rats, body weight did not increase as much, while apprehensible body weight increase was observed in hyperglycemic rats fed with bitter melon. Increase in body weight was more pronounced in hyperglycemic rats fed with $300 \mathrm{mg} / \mathrm{kg}$ body weight of bitter melon than $150 \mathrm{mg} / \mathrm{kg}$ body weight.

Table 3. Impact of bitter melon supplementation on body weight of rats.

\begin{tabular}{|c|c|c|c|c|}
\hline \multirow{3}{*}{ Groups } & \multicolumn{4}{|c|}{ Body Weight (G) } \\
\hline & \multicolumn{2}{|c|}{ 28th Day } & \multicolumn{2}{|c|}{ 56th Day } \\
\hline & Normal Rats & Hyperglycemic Rats & Normal Rats & Hyperglycemic Rats \\
\hline Control & $158.66 \pm 3.01^{\mathrm{a}}$ & $145.55 \pm 2.75^{c}$ & $215.90 \pm 4.22^{\mathrm{a}}$ & $181.34 \pm 2.61^{c}$ \\
\hline SF-L & $155.91 \pm 2.77^{b}$ & $151.18 \pm 2.04^{b}$ & $208.67 \pm 4.06^{b}$ & $203.66 \pm 3.59^{b}$ \\
\hline SF-H & $154.75 \pm 3.52^{\mathrm{c}}$ & $151.66 \pm 1.89^{a, b}$ & $208.40 \pm 2.88^{b}$ & $205.33 \pm 3.11^{\mathrm{a}}$ \\
\hline FF-L & $154.62 \pm 1.95^{c}$ & $151.43 \pm 2.09^{b}$ & $208.33 \pm 2.54^{b}$ & $204.50 \pm 3.49^{b}$ \\
\hline FF-H & $154.34 \pm 2.67^{c}$ & $152.57 \pm 2.67^{\mathrm{a}}$ & $208.13 \pm 1.97^{b}$ & $206.56 \pm 3.34^{\mathrm{a}}$ \\
\hline WF-L & $154.32 \pm 3.00^{\mathrm{c}}$ & $151.71 \pm 0.95^{b}$ & $208.26 \pm 2.42^{b}$ & $204.66 \pm 2.68^{b}$ \\
\hline WF-H & $153.68 \pm 2.18^{d}$ & $152.83 \pm 1.90^{\mathrm{a}}$ & $208.01 \pm 2.97^{b}$ & $206.60 \pm 2.36^{\mathrm{a}}$ \\
\hline
\end{tabular}

Abbreviations and description as in Table 1.

\subsection{Estimation of Urine and Reducing Sugar Excretion}

The hyperglycemic rats produced more urine than the normal rats. This polyuria condition prevailed in hyperglycemic control group (Table 4 ). The dietary supplementation of bitter melon unveiled substantial decrease in urine excretion.

Table 4. Impact of bitter melon supplementation on urine volume of rats.

\begin{tabular}{|c|c|c|c|c|}
\hline \multirow{3}{*}{ Groups } & \multicolumn{4}{|c|}{ Urine Volume (mL/24 h) } \\
\hline & \multicolumn{2}{|c|}{ 28th Day } & \multicolumn{2}{|c|}{ 56th Day } \\
\hline & Normal Rats & Hyperglycemic Rats & Normal Rats & Hyperglycemic Rats \\
\hline Control & $14.3 \pm 2.23^{a}$ & $20.1 \pm 1.01^{a}$ & $18.3 \pm 1.13^{\mathrm{a}}$ & $26.8 \pm 2.85^{a}$ \\
\hline SF-L & $13.7 \pm 1.72^{b}$ & $16.5 \pm 2.19^{b}$ & $17.6 \pm 1.31^{\mathrm{b}}$ & $21.3 \pm 3.03^{b}$ \\
\hline SF-H & $13.6 \pm 1.63^{b}$ & $15.8 \pm 1.43^{b}$ & $17.5 \pm 0.99^{b}$ & $20.65 \pm 1.26^{b}$ \\
\hline FF-L & $13.3 \pm 0.76^{\mathrm{b}, \mathrm{c}}$ & $15.7 \pm 1.29 b$ & $17.3 \pm 1.84^{b}$ & $20.4 \pm 1.64^{b}$ \\
\hline FF-H & $13.3 \pm 1.33^{b, c}$ & $14.9 \pm 2.07^{b}$ & $16.9 \pm 1.22^{b, c}$ & $20.2 \pm 2.13^{b, c}$ \\
\hline WF-L & $13.2 \pm 0.89^{c}$ & $15.2 \pm 0.96^{\mathrm{c}}$ & $16.8 \pm 1.71^{\mathrm{c}}$ & $19.9 \pm 0.78^{c}$ \\
\hline WF-H & $13.0 \pm 2.13^{c}$ & $14.7 \pm 1.56^{\mathrm{d}}$ & $16.7 \pm 2.17^{c}$ & $19.7 \pm 1.16^{c}$ \\
\hline
\end{tabular}


The amount of reducing sugar in excreted urine was negligible (in milligrams) in normal control and experimental rats (Table 5). The urine samples of hyperglycemic control rats showed large quantity of reducing sugar and decreased considerably in rats fed with diet containing skin, flesh and whole fruit of bitter melon. The most potent dose was $300 \mathrm{mg} / \mathrm{kg}$ body weight of the whole fruit of bitter melon in reducing glycosuria condition followed by flesh and skin.

Table 5. Impact of bitter melon supplementation on reducing sugar in urine.

\begin{tabular}{ccccc}
\hline & \multicolumn{3}{c}{ Reducing Sugar in Urine (G) } \\
\cline { 2 - 5 } Groups & \multicolumn{2}{c}{ 28th Day } & 56th Day \\
\cline { 2 - 5 } & Normal Rats & Hyperglycemic Rats & Normal Rats & Hyperglycemic Rats \\
\cline { 2 - 5 } & $0.02 \pm 0.00^{\mathrm{a}}$ & $2.91 \pm 0.32^{\mathrm{a}}$ & $0.02 \pm 0.01^{\mathrm{a}}$ & $4.32 \pm 0.75^{\mathrm{a}}$ \\
Control & $0.03 \pm 0.02^{\mathrm{a}}$ & $2.16 \pm 0.11^{\mathrm{b}}$ & $0.03 \pm 0.02^{\mathrm{a}}$ & $2.18 \pm 0.42^{\mathrm{b}}$ \\
SF-L & $0.02 \pm 0.01^{\mathrm{a}}$ & $1.86 \pm 0.21^{\mathrm{c}}$ & $0.02^{\mathrm{a}} \pm 0.01^{\mathrm{a}}$ & $1.96 \pm 0.38^{\mathrm{b}}$ \\
SF-H & $0.05 \pm 0.02^{\mathrm{a}}$ & $1.99 \pm 0.36^{\mathrm{c}}$ & $0.04 \pm 0.02^{\mathrm{a}}$ & $2.02 \pm 0.33^{\mathrm{b}}$ \\
FF-L & $0.02 \pm 0.00^{\mathrm{a}}$ & $1.58 \pm 0.58^{\mathrm{c}}$ & $0.02 \pm 0.01^{\mathrm{a}}$ & $1.74 \pm 0.27^{\mathrm{c}}$ \\
FF-H & $0.02 \pm 0.01^{\mathrm{a}}$ & $1.87 \pm 0.13^{\mathrm{c}}$ & $0.03 \pm 0.00^{\mathrm{a}}$ & $1.89 \pm 0.14^{\mathrm{b}}$ \\
WF-L & $0.03 \pm 0.01^{\mathrm{a}}$ & $1.43 \pm 0.19^{\mathrm{d}}$ & $0.02 \pm 0.00^{\mathrm{a}}$ & $1.63 \pm 0.36^{\mathrm{c}}$ \\
WF-H & & & & \\
\hline
\end{tabular}

Abbreviations and description as in Table 1.

\subsection{Estimation of Kidney Weight}

The assessment of renal hypertrophy was determined by observing the kidney weights in relation to $100 \mathrm{~g}$ body weight (Table 6). Normal rats showed no abnormal increase in kidney weight. During hyperglycemic conditions, increase in kidney weight is more obvious in control rats specifying renal hypertrophy. Bitter melon dietary supplementation significantly reduced this condition.

Table 6. Impact of bitter melon supplementation on kidney weight.

\begin{tabular}{|c|c|c|c|c|}
\hline \multirow{2}{*}{ Groups } & \multicolumn{2}{|c|}{$\begin{array}{l}\text { Kidney Weight (G) } \\
\text { in Normal Rats }\end{array}$} & \multicolumn{2}{|c|}{$\begin{array}{c}\text { Kidney Weight (G) } \\
\text { in Hyperglycemic Rats }\end{array}$} \\
\hline & Right & Left & Right & Left \\
\hline Control & $0.69 \pm 0.04^{\mathrm{a}}$ & $0.68 \pm 0.01^{\mathrm{a}}$ & $0.89 \pm 0.06^{\mathrm{a}}$ & $0.87 \pm 0.03^{a}$ \\
\hline SF-L & $0.64 \pm 0.03^{b}$ & $0.63 \pm 0.02^{b}$ & $0.78 \pm 0.03^{b}$ & $0.78 \pm 0.02^{b}$ \\
\hline SF-H & $0.63 \pm 0.02^{b}$ & $0.62 \pm 0.01^{b}$ & $0.76 \pm 0.04^{c}$ & $0.77 \pm 0.02^{b}$ \\
\hline FF-L & $0.64 \pm 0.02^{b}$ & $0.63 \pm 0.03^{b}$ & $0.76 \pm 0.03^{c}$ & $0.75 \pm 0.04^{\mathrm{c}}$ \\
\hline FF-H & $0.62 \pm 0.01^{\mathrm{c}}$ & $0.62 \pm 0.04^{b}$ & $0.74 \pm 0.03^{d}$ & $0.72 \pm 0.03^{\mathrm{d}}$ \\
\hline WF-L & $0.64 \pm 0.03^{b}$ & $0.62 \pm 0.02^{b}$ & $0.69 \pm 0.02^{\mathrm{e}}$ & $0.70 \pm 0.01^{\mathrm{d}, \mathrm{e}}$ \\
\hline WF-H & $0.62 \pm 0.02^{c}$ & $0.62 \pm 0.02^{b}$ & $0.68 \pm 0.02 \mathrm{e}^{\mathrm{e}}$ & $0.68 \pm 0.02 \mathrm{e}$ \\
\hline
\end{tabular}

Abbreviations and description as in Table 1.

\subsection{Estimation of Glomerular Filtration Rate}

Significantly higher glomerular filtration rate (Table 7) was noticed in hyperglycemic control rats and regular bitter gourd consumption in these rats markedly influenced this trait to normalization. 
Table 7. Impact of bitter melon supplementation on glomerular filtration rate of rats.

\begin{tabular}{ccc}
\hline \multirow{2}{*}{ Groups } & \multicolumn{2}{c}{ Glomerular Filtration Rate (mL/min) } \\
\cline { 2 - 3 } & Normal Rats & Hyperglycemic Rats \\
\hline Control & $1.13 \pm 0.13^{\mathrm{a}}$ & $3.32 \pm 0.33^{\mathrm{a}}$ \\
SF-L & $1.06 \pm 0.09^{\mathrm{b}}$ & $2.76 \pm 0.27^{\mathrm{b}}$ \\
SF-H & $1.04 \pm 0.11^{\mathrm{b}}$ & $2.70 \pm 0.28^{\mathrm{b}}$ \\
FF-L & $1.04 \pm 0.16^{\mathrm{b}}$ & $2.75 \pm 0.22^{\mathrm{b}}$ \\
FF-H & $1.03 \pm 0.07^{\mathrm{b}, \mathrm{c}}$ & $2.63 \pm 0.31^{\mathrm{b}}$ \\
WF-L & $1.04 \pm 0.09^{\mathrm{b}}$ & $2.45 \pm 0.21^{\mathrm{c}}$ \\
WF-H & $1.01 \pm 0.14^{\mathrm{c}}$ & $2.33 \pm 0.14^{\mathrm{c}}$ \\
\hline
\end{tabular}

Abbreviations and description as in Table 1.

\subsection{Estimation of Blood Glucose}

In normal rats, due to feeding of bitter melon, blood sugar level was maintained in experimental group of rats. In hyperglycemic rats, blood sugar level reduced significantly in experimental groups. The maximum reduction was observed in rats fed with whole fruit of bitter gourd (300 mg/kg body weight) in both 28th (Figure 2) and 56th (Figure 3) day samples.

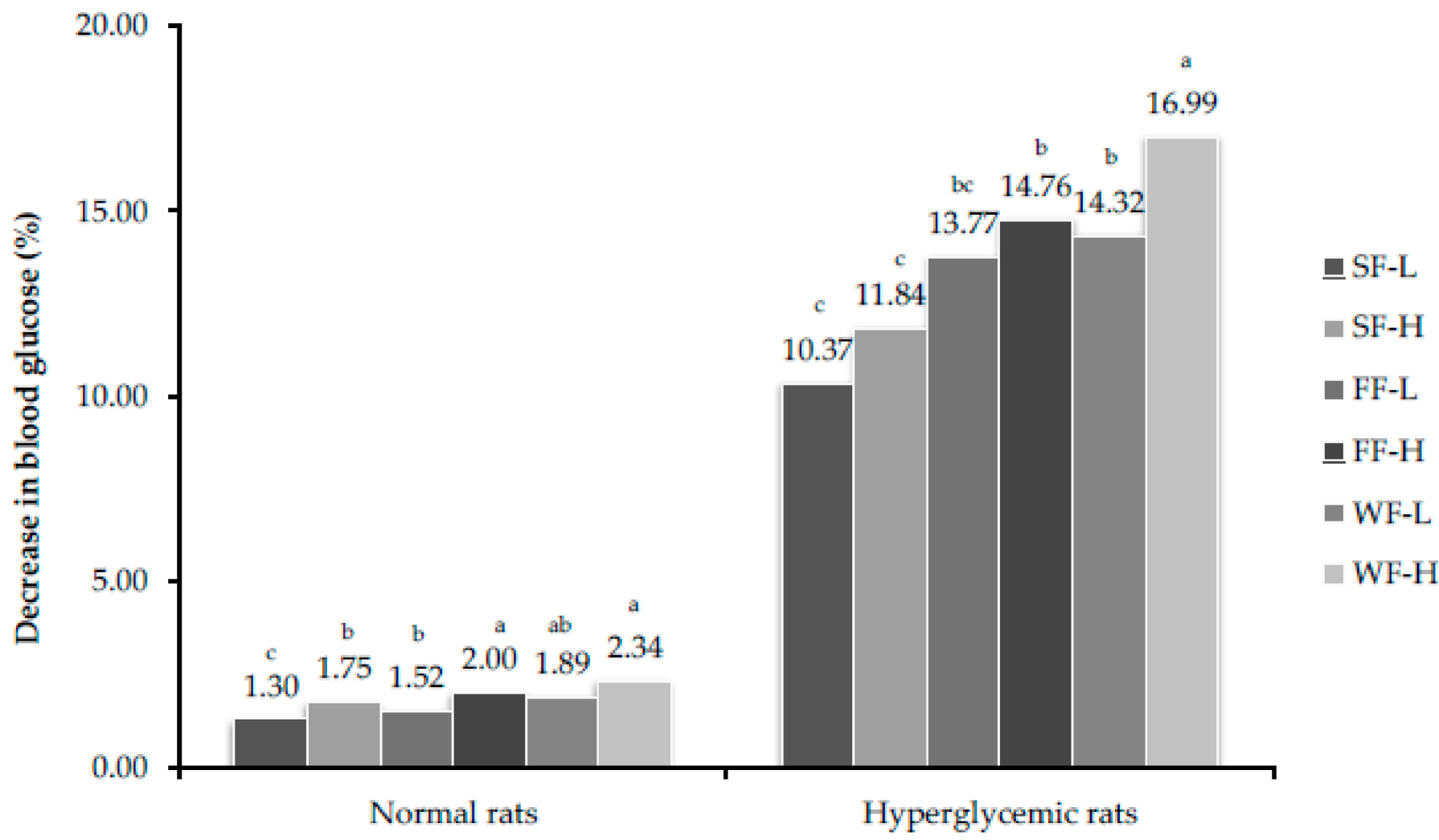

Figure 2. Percent decrease in glucose level after feeding bitter gourd on 28th day. Bars that do not share similar letters denote statistical significance $(p<0.05)$. 


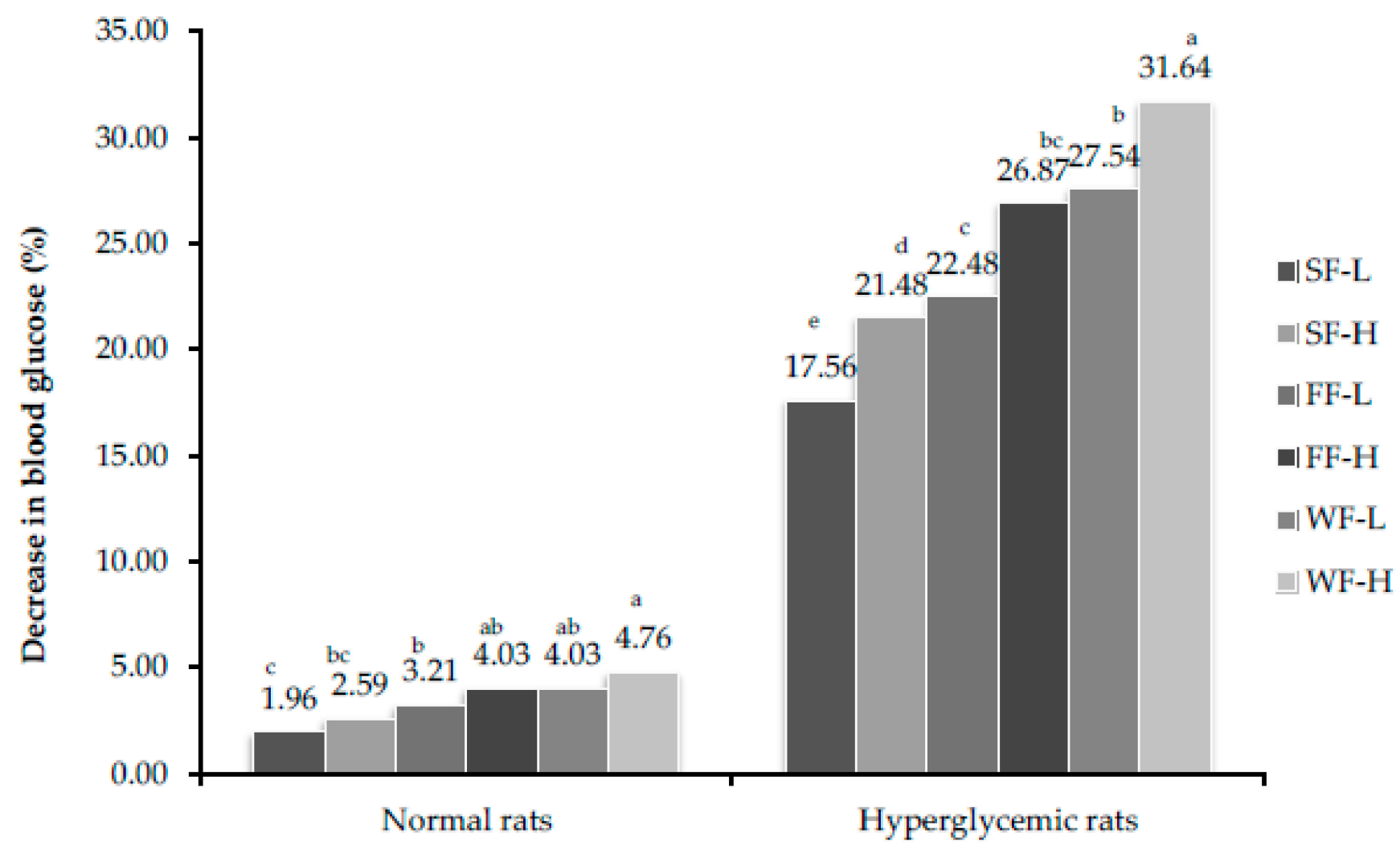

Figure 3. Percent decrease in glucose level after feeding bitter gourd on 56th day. Bars that do not share similar letters denote statistical significance $(p<0.05)$.

\subsection{Estimation of Insulin Concentration}

Skin, flesh and whole fruit of bitter melon in diet induced a significant increase in insulin release from the pancreas of diabetic rats at both low $(150 \mathrm{mg} / \mathrm{kg}$ body weight $)$ and high (300 mg/ $\mathrm{kg}$ body weight) concentrations in a dose dependent manner as compared to control values in normal and hyperglycemic rats. Skin fed rats showed a lesser effect on insulin release compared to flesh and whole fruit. Treatments of hyperglycemic rats with bitter melon for 4 and 8 weeks resulted in significant increase in insulin production (Figures 4 and 5). This section may be divided by subheadings. It should provide a concise and precise description of the experimental results and their interpretation, as well as the experimental conclusions that can be drawn. 


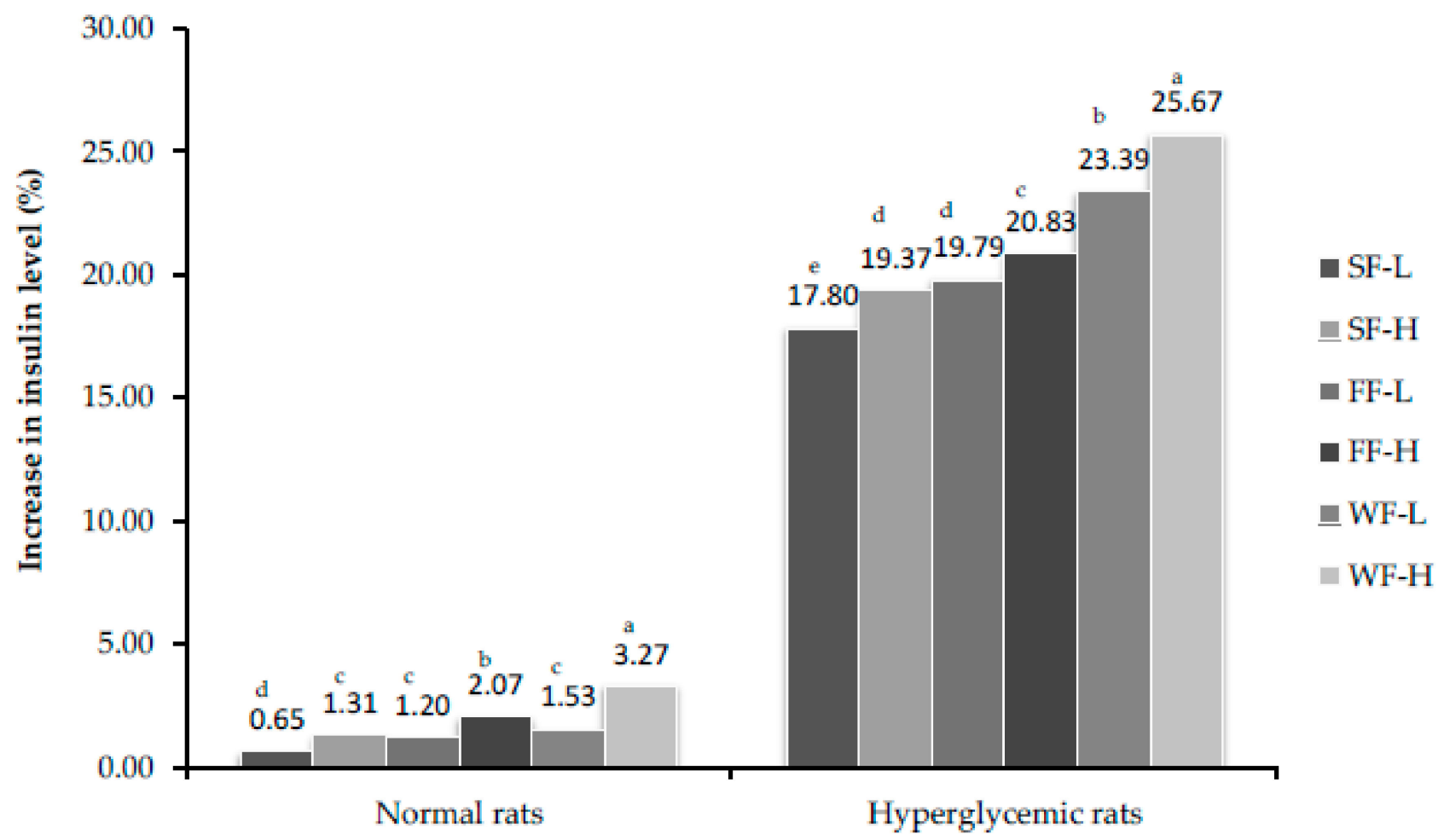

Figure 4. Percent increase in insulin level after feeding bitter gourd on 28th day. Bars that do not share similar letters denote statistical significance $(p<0.05)$.

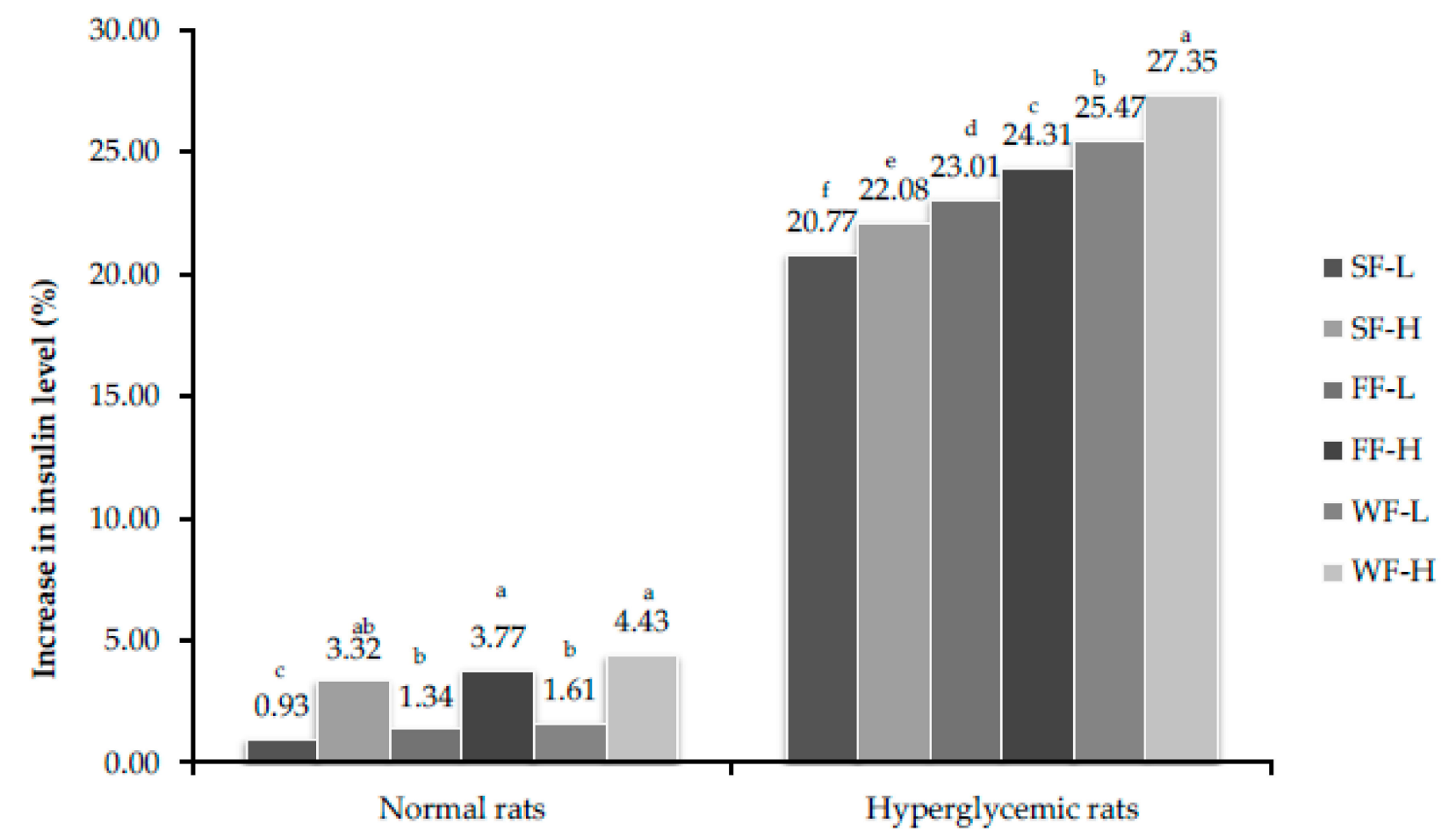

Figure 5. Percent increase in insulin level after feeding bitter gourd on 56th day. Bars that do not share similar letters denote statistical significance $(p<0.05)$. 


\section{Discussion}

There is an erratic approach in the literature regarding effectiveness of bitter melon on glucose control to make a decisive conclusion. The present, detailed study highlighted the effectiveness of skin, flesh and whole fruit containing seed as a dietary approach against development of diabetes and its treatment. The present results clearly revealed that bitter melon given at $300 \mathrm{mg} / \mathrm{kg}$ body weight improved the diabetic status to a reasonable extent. Bitter melon possessed high concentration of hypoglycemic agents like charantin and vicine, which are the mainstays in treatment of diabetes. Charantin and vicine contents were first observed in skin, flesh and whole fruit containing seeds before bio-evaluation. Pitipanapong et al. [15], Ham and Wang [23] and Desai et al. [24] reported variable concentration of charantin in this plant. Similarly, a higher amount of vicine was assessed in seeds than fruit and leaves by Zhang et al. [16]. The skin, flesh and whole fruit of bitter melon with known quantities of charantin and vicine were administered in daily diet of experimental rats.

Improvements in diabetic conditions were observed after giving bitter melon. The increase in water intake in experimental groups of normal rats is due to increase in metabolic rate and fatty acid metabolism after incorporation of bitter melon in diet. The excessive water consumption by hyperglycemic rats is primarily associated with pre-diabetic state and characteristic sign of onset of diabetes. This notion is favored by the findings of Parmar et al. [25], who reported high intake of water in hyperglycemic rats. In diabetic rats, intake of water gradually reduced after giving bitter melon [25].

Feed intake reduced to certain degree due to incorporation of bitter melon in diet. Chen et al. [26], Reyes et al. [27] and Huang et al. [28] also observed lesser feed intake in rats after adding bitter melon, but this impact is trivial to be considered or even in some cases have no impact on feed intake [29]. The gradual increase in body weight was observed in normal control, whereas that increase was lesser in diabetic control rats. The other diabetic groups of rat that fed on bitter melon, improvement in body weight was observed [30]. Bitter melon inclusions in the diet prevent the polyuria condition associated with diabetes. In hyperglycemic rats, urine sugar was very high and in agreement with previous studies [31]. Dietary supplementation of bitter melon minimizes sugar excretion in urine during diabetes. Increase in kidney size and malfunctioning is generally associated with diabetes. This increase is mainly due to increase in diameter and length of capillaries. In current study, bitter gourd supplementation has resulted in partial but significant decrease in ratio of kidney to body weight. Increase in glomerular filtration rate in hyperfunctional kidney mostly occurs during the initial diabetic stage [32] and metabolic control for a long period is helpful in reducing kidney filtration during diabetes [33]. In our study, the glomerular filtration rate increased considerably in hyperglycemic control. The feeding of bitter melon to hyperglycemic rats showed significant reduction in glomerular filtration rate. The hypoglycemic ability of bitter gourd is discussed in different scientific explorations, advocating its use in various forms. The results regarding reduction in blood glucose level by consuming bitter melon are in accordance with the findings of Jafri et al. [30]. In their study, hyperglycemic rats showed a substantial decrease in glucose when fed with bitter melon powder. In another study, acetone extract of whole bitter melon fruit powder was used in doses of 25,50 and $75 \mathrm{mg} / 100 \mathrm{~g}$ body weight and was observed to have significant blood glucose lowering ability (13.30 to $50 \%)$ in alloxan diabetic albino rats [34]. On the other hand, some studies reported contradictory results of bitter melon intake with no positive effect in lowering blood glucose level and diabetic conditions [12,13].

The hypoglycemic ability of bitter melon is due to presence of bioactive molecules that play a pivotal role in many physiological, pharmacological and biochemical processes [35]. The possible factors involved in reducing blood glucose level by bitter melon consumption include skeletal and peripheral muscles stimulation to enhance glucose utilization [36,37], preventing uptake of glucose from intestine [38-40], maintaining enzymatic activities related to glucose metabolism [41], restoring stability of pancreatic $\beta$-cells and increasing their functionality [42]. Bitter melon contains charantin and vicine, which are collectively 
found more effective in diabetes management as charantin is a typical cucurbitane-type triterpenoid in M. charantia and is a potential substance with antidiabetic properties. Charantin could be used to treat diabetes and can potentially replace treatment. It is a mixture of two compounds, namely, sitosteryl glucoside and stigmasteryl glucoside [43].

In the present study, bitter melon supplemented feed had a positive effect on pancreatic cells to enhance insulin secretion and maintenance of serum insulin level $[44,45]$. This increase in insulin production might be due to $\beta$-cells structural and functional stability after consuming diet supplemented with bitter melon [34,43] or increasing the number of $\beta$-cells in Islets of Langerhans [44]. According to Xiang et al. [46], certain chemical constituents in bitter melon operated as a growth factor for pancreatic $\beta$-cells. The presence of bioactive moieties that act as hypoglycemic agents including charantin and vicine are spontaneously involved in insulin production or possess insulin-like activity. The chemical constituents present in bitter melon help in minimizing oxidative damage by neutralization of free radicals activity and performing prompt actions to control the death of $\beta$-cells. From the above discussion, it is deduced that all parts of fruits of bitter melon are significantly effectual against diabetes and $300 \mathrm{mg} / \mathrm{kg}$ body weight of whole fruit was the most potent dose and can be preferred for use in hyperglycemic conditions and diabetes prophylaxis and treatment.

\section{Conclusions}

It is concluded that charantin is present in a large quantity in flesh parts and vicine is mainly concentrated in the whole fruit containing seeds. Current research intervention suggested that individual phytochemical like charantin or vicine is less effective in diabetes management. The complex interaction of these hypoglycemic agents of bitter melon can play a more operative role in delaying the pathogenesis of diabetes mellitus. However, the clinical studies following the double blind randomized controlled trials on human subjects must be conducted to warrant their use in humans.

Author Contributions: Conceptualization, M. and F.S.; investigation, M.; writing-original draft preparation, M.T.S.; S.A., and R.A., writing-review and editing, N.B.; R.M. and A.R. All authors have read and agreed to the published version of the manuscript.

Funding: This research was funded by Higher Education Commission, Islamabad, Pakistan, grant number 2AV2-124.

Institutional Review Board Statement: Central Government Ethical Committee Guidelines were strictly followed during the course of study (Approval no. FSD-16/M-234).

Informed Consent Statement: Not applicable.

Data Availability Statement: All the data produced here is available and can produced when required.

Conflicts of Interest: The authors declare no conflict of interest.

\section{References}

1. Grover, J.K.; Yadav, S.; Vats, V. Medicinal plants of India with anti-diabetic potential. J. Ethnopharmacol. 2002, 81, 81-100. [CrossRef]

2. Gupta, M.; Sharma, S.; Gautam, A.; Bhadauria, R. Momordica charantia Linn. (Karela): Nature's silent healer. Int. J. Pharm. Sci. Rev. Res. 2011, 11, 32-37.

3. Virdi, J.; Sivakami, S.; Shahani, S.; Suthar, A.C.; Banavalikar, M.M.; Biyani, M.K. Antihyperglycemic effects of three extracts from Momordica charantia. J. Ethnopharmacol. 2003, 88, 107-111. [CrossRef]

4. Kulkarni, P.; Lohidasan, S.; Mahadik, K. Isolation, characterisation and investigation of in vitro antidiabetic and antioxidant activity of phytoconstituents from fruit of Momordica charantia Linn. Nat. Prod. Res. 2019, 1-3. [CrossRef]

5. Kim, S.K.; Jung, J.; Jung, J.H.; Yoon, N.; Kang, S.S.; Roh, G.S.; Hahm, J.R. Hypoglycemic efficacy and safety of Momordica charantia (bitter melon) in patients with type 2 diabetes mellitus. Complement. Ther. Med. 2020, 52, 102524. [CrossRef] [PubMed]

6. Cortez-Navarrete, M.; Martínez-Abundis, E.; Pérez-Rubio, K.G.; González-Ortiz, M.; Méndez-Del Villar, M. Momordica charantia Administration Improves Insulin Secretion in Type 2 Diabetes Mellitus. J. Med. Food 2018, 21, 672-677. [CrossRef]

7. Thent, Z.C.; Das, S.; Zaidun, N.H. Emerging Trends On Drug Delivery Strategy of Momordica charantia against Diabetes and its Complications. Curr. Drug Deliv. 2018, 15, 453-460. [CrossRef] 
8. Xu, X.; Shan, B.; Liao, C.H.; Xie, J.H.; Wen, P.W.; Shi, J.Y. Anti-diabetic properties of Momordica charantia L. polysaccharide in alloxan-induced diabetic mice. Int. J. Biol. Macromol. 2015, 81, 538-543. [CrossRef]

9. Jia, S.; Shen, M.; Zhang, F.; Xie, J. Recent Advances in Momordica charantia: Functional Components and Biological Activities. Int. J. Mol. Sci. 2017, 18, 2555. [CrossRef]

10. Tan, S.P.; Kha, T.C.; Parks, S.E.; Roach, P.D. Bitter melon (Momordica charantia L.) bioactive composition and health benefits: A review. Food. Rev. Int. 2016, 32, 181-202. [CrossRef]

11. Ooi, C.P.; Yassin, Z.; Hamid, T.A. Momordica charantia for type 2 diabetes mellitus. Cochrane Database Syst. Rev. 2010. [CrossRef]

12. Kasbia, G.S.; Arnason, J.T.; Imbeault, P. No effect of acute, single dose oral administration of Momordica charantia Linn., on glycemia, energy expenditure and appetite: A pilot study in non-diabetic overweight men. J. Ethnopharmacol. 2009, 126, 127-133. [CrossRef] [PubMed]

13. Yin, R.V.; Lee, N.C.; Hirpara, H.; Phung, O.J. The effect of bitter melon (Mormordica charantia) in patients with diabetes mellitus: A systematic review and meta-analysis. Nutr. Diabetes 2014, 4, e145. [CrossRef]

14. Peter, E.L.; Kasali, F.M.; Deyno, S.; Mtewa, A.; Nagendrappa, P.B.; Tolo, C.U.; Ogwang, P.E.; Sesaazi, D. Momordica charantia L. lowers elevated glycaemia in type 2 diabetes mellitus patients: Systematic review and meta-analysis. J. Ethnopharmacol. 2019, 231, 311-324. [CrossRef]

15. Pitipanapong, J.; Chitprasert, S.; Goto, M.; Jiratchariyakul, W.; Sasaki, M.; Shotipruk, A. New approach for extraction of charantin from Momordica charantia with pressurized liquid extraction. Sep. Purif. Technol. 2007, 52, 416-422. [CrossRef]

16. Zhang, H.; Wang, Y.; Zhang, X.; Liu, M.; Hu, Z. Analysis of vicine in bitter melon with high performance liquid chromatography. Anal. Lett. 2003, 36, 1597-1605. [CrossRef]

17. Miller, G.L. Use of dinitrosalicylic acid reagent for determination of reducing sugar. Anal. Chem. 1959, 31, 426-428. [CrossRef]

18. Owen, J.A.; Iggo, B.; Scandrett, F.J.; Stewart, C.P. The determination of creatinine in plasma or serum, and in urine; a critical examination. Biochem. J. 1954, 58, 426-437. [CrossRef] [PubMed]

19. Yokozawa, T.; Chung, H.Y.; He, L.Q.; Oura, H. Effectiveness of green tea tannin on rats with chronic renal failure. Biosci. Biotechnol. Biochem. 1996, 60, 1000-1005. [CrossRef]

20. Katz, A.; Nambi, S.S.; Mather, K.; Baron, A.D.; Follmann, D.A.; Sullivan, G.; Quon, M.J. Quantitative insulin sensitivity check index: A simple, accurate method for assessing insulin sensitivity in humans. J. Clin. Endocrinol. Metab. 2000, 85, 2402-2410. [CrossRef]

21. Ahn, J.; Choi, W.; Kim, S.; Ha, T. Anti-diabetic effect of watermelon (Citrullus vulgaris Schrad) on Streptozotocin-induced diabetic mice. Food Sci. Biotechnol. 2011, 20, 251-254. [CrossRef]

22. Steel, R.G.; Torrie, J.H. Principles and Procedures of Statistics: A Biometrical Approach; McGraw-Hill: New York, NY, USA, 1986.

23. Han, C.; Wang, J. Optimization of conditions for charantin extraction in PEG/Salt aqueous two-phase systems using response surface methodology. Open Complemen. Med. J. 2009, 1, 46-50. [CrossRef]

24. Desai, S.; Tatke, P.; Mane, T.; Gabhe, S. Isolation, characterization and quantitative HPLC-DAD analysis of components of charantin from fruits of Momordica charantia. Food Chem. 2020, 345, 128717. [CrossRef]

25. Parmar, K.; Patel, S.; Patel, J.; Patel, B.; Patel, M. Effects of bittergourd (Momordica charantia) fruit juice on glucose tolerance and lipid profile in type-II diabetic rats. Int. J. Drug Dev. Res. 2011, 3, 139-146.

26. Chen, Q.; Chan, L.L.; Li, E.T. Bitter melon (Momordica charantia) reduces adiposity, lowers serum insulin and normalizes glucose tolerance in rats fed a high fat diet. J. Nutr. 2003, 133, 1088-1093. [CrossRef] [PubMed]

27. Reyes, B.A.; Bautista, N.D.; Tanquilut, N.C.; Anunciado, R.V.; Leung, A.B.; Sanchez, G.C.; Magtoto, R.L.; Castronuevo, P.; Tsukamura, H.; Maeda, K.I. Anti-diabetic potentials of Momordica charantia and Andrographis paniculata and their effects on estrous cyclicity of alloxan-induced diabetic rats. J. Ethnopharmacol. 2006, 105, 196-200. [CrossRef]

28. Huang, H.L.; Hong, Y.W.; Wong, Y.H.; Chen, Y.N.; Chyuan, J.H.; Huang, C.J.; Chao, P.M. Bitter melon (Momordica charantia L.) inhibits adipocyte hypertrophy and down regulates lipogenic gene expression in adipose tissue of diet-induced obese rats. $\mathrm{Br}$. $\mathrm{J}$. Nutr. 2008, 99, 230-239. [CrossRef]

29. Klomann, S.D.; Mueller, A.S.; Pallauf, J.; Krawinkel, M.B. Antidiabetic effects of bitter gourd extracts in insulin-resistant db/db mice. Br. J. Nutr. 2010, 104, 1613-1620. [CrossRef]

30. Jafri, S.; Ismail, M.; Zaman, G. Effect of Momordica charantia (karela) in alloxan induced diabetic rats. Pak. J. Sci. 2009, 61, 220.

31. Nandini, C.D.; Sambaiah, K.; Salimath, P.V. Dietary fibres ameliorate decreased synthesis of heparan sulphate in streptozotocin induced diabetic rats. J. Nutr. Biochem. 2003, 14, 203-210. [CrossRef]

32. Christiansen, J.S.; Gammelgaard, J.; Frandsen, M.; Parving, H.H. Increased kidney size, glomerular filtration rate and renal plasma flow in short-term insulin-dependent diabetics. Diabetologia 1981, 20, 451-456. [CrossRef]

33. Feldt-Rasmussen, B.; Hegedüs, L.; Mathiesen, E.; Deckert, T. Kidney volume in type 1 (insulin-dependent) diabetic patients with normal or increased urinary albumin excretion: Effect of long-term improved metabolic control. Scand. J. Clin. Lab. Investig. 1991, 51, 31-36. [CrossRef]

34. Singh, N.; Gupta, M. Regeneration of beta cells in islets of Langerhans of pancreas of alloxan diabetic rats by acetone extract of Momordica charantia (Linn.) (bitter gourd) fruits. Ind. J. Exp. Biol. 2007, 45, 1055-1062. [PubMed]

35. Bhushan, M.S.; Rao, C.; Ojha, S.; Vijayakumar, M.; Verma, A. An analytical review of plants for anti diabetic activity with their phytoconstituent and mechanism of action. Int. J. Pharm. Sci. Res. 2010, 1, 29-46. [CrossRef]

36. Cummings, D.E.; Overduin, J. Gastrointestinal regulation of food intake. J. Clin. Investig. 2007, 117, 13-23. [CrossRef] 
37. Akhtar, N.; Khan, B.A.; Majid, A.; Khan, H.M.; Mahmood, T.; Gulfishan; Saeed, T. Pharmaceutical and biopharmaceutical evaluation of extracts from different plant parts of indigenous origin for their hypoglycemic responses in rabbits. Acta Pol. Pharm. 2011, 68, 919-925. [PubMed]

38. Uebanso, T.; Arai, H.; Taketani, Y.; Fukaya, M.; Yamamoto, H.; Mizuno, A.; Uryu, K.; Hada, T.; Takeda, E. Extracts of Momordica charantia suppress postprandial hyperglycemia in rats. J. Nutr. Sci. Vitaminol. 2007, 53, 482-488. [CrossRef] [PubMed]

39. Jeong, J.-H.; Lee, S.-H.; Hue, J.-J.; Lee, K.-N.; Nam, S.Y.; Yun, Y.W.; Jeong, S.-w.; Lee, Y.H.; Lee, B.J. Effect of bitter melon (Momordica charantia) on anti-diabetic activity in C57BLI/6J db/db mice. Korean J. Vet. Res. 2008, 48, 327-336.

40. Abdollah, M.; Zuki, A.; Goh, Y.; Rezaeizadeh, A.; Noordin, M. The effects of Momordica charantia on the liver in streptozotocininduced diabetes in neonatal rats. Afr. J. Biotechnol. 2010, 9, 5004-5012.

41. Shibib, B.A.; Khan, L.A.; Rahman, R. Hypoglycaemic activity of Coccinia indica and Momordica charantia in diabetic rats: Depression of the hepatic gluconeogenic enzymes glucose-6-phosphatase and fructose-1,6-bisphosphatase and elevation of both liver and red-cell shunt enzyme glucose-6-phosphate dehydrogenase. Biochem. J. 1993, 292, 267-270. [CrossRef]

42. Gadang, V.; Gilbert, W.; Hettiararchchy, N.; Horax, R.; Katwa, L.; Devareddy, L. Dietary bitter melon seed increases peroxisome proliferator-activated receptor- $\gamma$ gene expression in adipose tissue, down-regulates the nuclear factor- $\mathrm{kB}$ expression, and alleviates the symptoms associated with metabolic syndrome. J. Med. Food 2011, 14, 86-93. [CrossRef]

43. Joseph, B.; Jini, D. Antidiabetic effects of Momordica charantia (bitter melon) and its medicinal potency. Asian Pac. J. Trop. Dis. 2013, 3, 93-102. [CrossRef]

44. Fernandes, N.P.; Lagishetty, C.V.; Panda, V.S.; Naik, S.R. An experimental evaluation of the antidiabetic and antilipidemic properties of a standardized Momordica charantia fruit extract. BMC Complement. Altern. Med. 2007, 7, 29. [CrossRef]

45. Mohammady, I.; Elattar, S.; Mohammed, S.; Ewais, M. An evaluation of anti-diabetic and anti-lipidemic properties of Momordica charantia (bitter melon) fruit extract in experimentally induced diabetes. Life Sci. J. 2012, 9, 363-374.

46. Xiang, L.; Huang, X.; Chen, L.; Rao, P.; Ke, L. The reparative effects of Momordica charantia Linn. extract on HIT-T15 pancreatic beta-cells. Asia Pac. J. Clin. Nutr. 2007, 16 (Suppl. 1), 249-252. [PubMed] 